\title{
Barite-A Case Study of Import Reliance on an Essential Material for Oil and Gas Exploration and Development Drilling
}
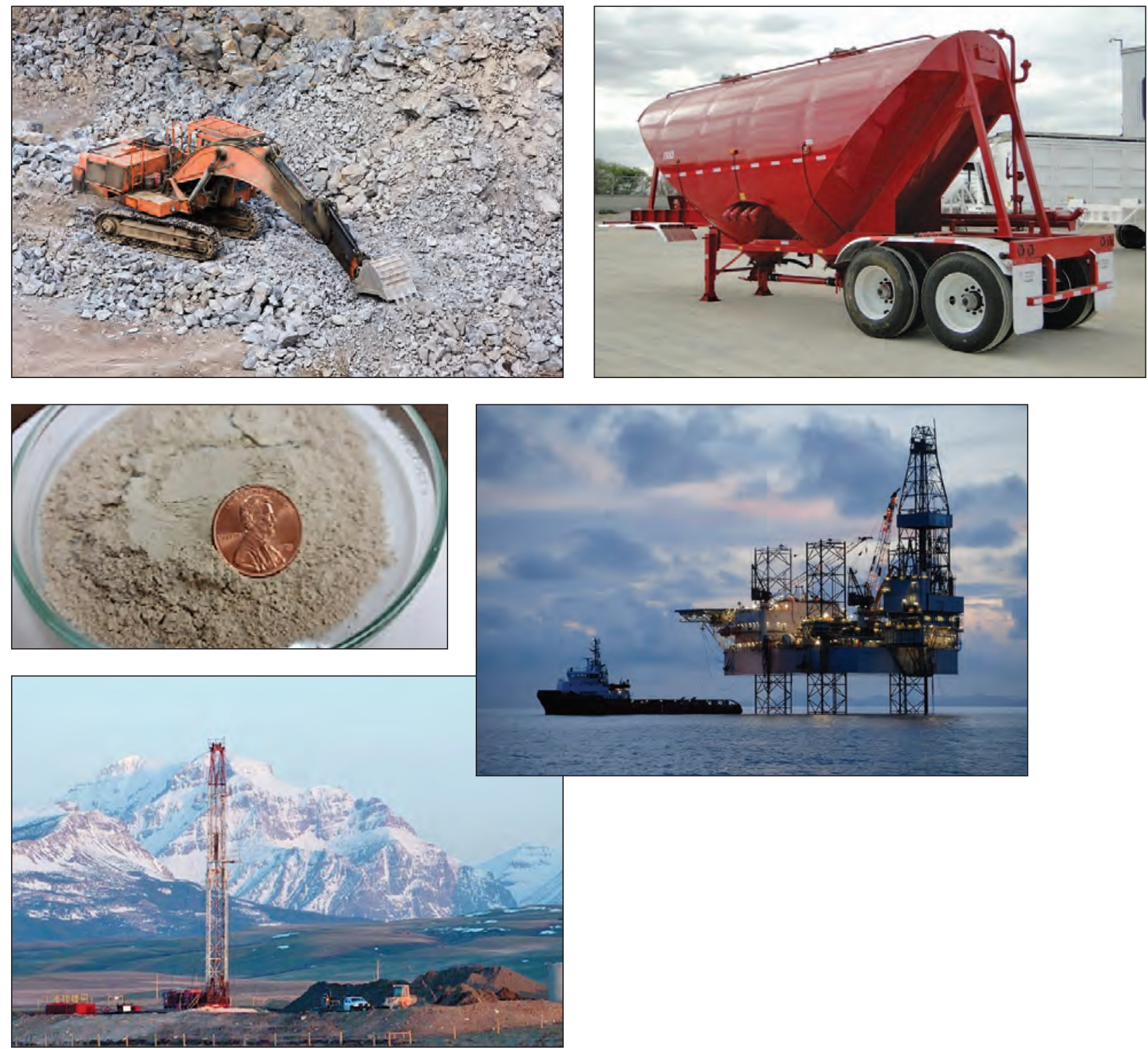

Scientific Investigations Report 2014-5230

U.S. Department of the Interior

U.S. Geological Survey 
Cover photographs (clockwise from top left). Barite mine in Mexico (courtesy of Desku Group, Inc.); trailer used to transport dried and finely ground barite to a drill site for use as an additive to drilling fluid (courtesy of Drillingbarite.com); offshore oil drilling platform and supply vessel which transports cargoes of drilling fluid and other materials in support of drilling activities (courtesy of Maritime Executive Magazine); oil and gas drilling rig located on the Blackfeet Reservation in Northwest Montana (courtesy of Tony Bynum of Tony Bynum Photography); ground drilling-grade barite (courtesy of Global Energy Laboratories). 


\section{Barite-A Case Study of Import Reliance on an Essential Material for Oil and Gas Exploration and Development Drilling}

By Donald I. Bleiwas and M. Michael Miller

Scientific Investigations Report 2014-5230 


\title{
U.S. Department of the Interior SALLY JEWELL, Secretary
}

\section{U.S. Geological Survey Suzette M. Kimball, Acting Director}

\author{
U.S. Geological Survey, Reston, Virginia: 2015
}

For more information on the USGS - the Federal source for science about the Earth, its natural and living resources, natural hazards, and the environment—visit http://www.usgs.gov or call 1-888-ASK-USGS.

For an overview of USGS information products, including maps, imagery, and publications, visit http://www.usgs.gov/pubprod/.

Any use of trade, firm, or product names is for descriptive purposes only and does not imply endorsement by the U.S. Government.

Although this information product, for the most part, is in the public domain, it also may contain copyrighted materials as noted in the text. Permission to reproduce copyrighted items must be secured from the copyright owner.

Suggested citation:

Bleiwas, D.I., and Miller, M.M., 2015, Barite-A case study of import reliance on an essential material for oil and gas exploration and development drilling: U.S. Geological Survey Scientific Investigations Report 2014-5230, 6 p., http://dx.doi.org/10.3133/sir20145230.

ISSN 2328-0328 (online) 


\section{Contents}

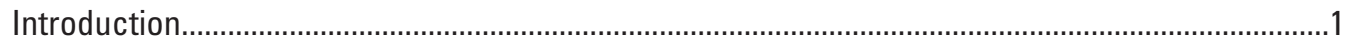

Drilling for Oil and Gas: The Primary Use for Barite .................................................................

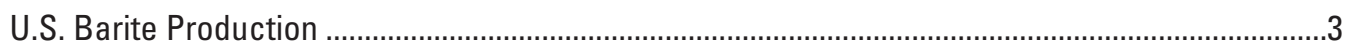

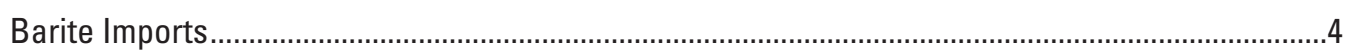

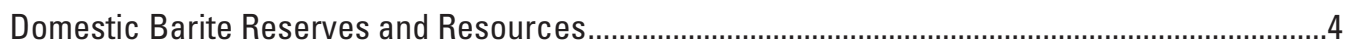

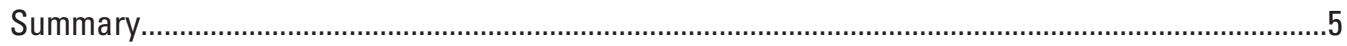

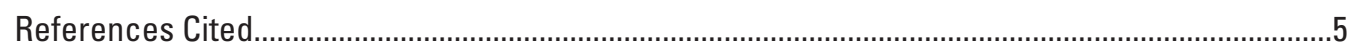

\section{Figures}

1. Comparison of domestic barite production in metric tons with its percentage share of total barite used for drilling in the United States in selected years ....................2

2. Metric tons of domestic and imported barite, by country, prices, and percent of U.S. barite consumption used for drilling in the United States in selected years.........2

\section{Conversion Factors}

\begin{tabular}{lcl}
\hline \multicolumn{1}{c}{ Multiply } & By & To obtain \\
\hline meter $(\mathrm{m})$ & Length & \\
\hline & 3.28 & foot $(\mathrm{ft})$ \\
\hline metric ton per year (t/yr) & Mass & \\
\hline
\end{tabular}





\title{
Barite-A Case Study of Import Reliance on an Essential Material for Oil and Gas Exploration and Development Drilling
}

\author{
By Donald I. Bleiwas and M. Michael Miller
}

\section{Introduction}

Global dependence on a limited number of countries for specific mineral commodities could lead to sudden supply disruptions for the United States, and barite is one such commodity. Analyses of barite supply amounts and sources for the United States are demonstrative of mineral commodities on which the country is import reliant. Mineral commodity trade flows can be analyzed more easily than import reliances for commodities in which U.S. domestic demand is primarily met by materials contained within manufactured products, as with the rare-earth elements in cellular phones and computers. Barite plays an essential role as a weighting material in drilling muds used in oil and gas drilling, primarily to prevent the explosive release of gas and oil during drilling. The Nation's efforts to become more energy independent are based largely on the domestic oil and gas industry's ability to explore and develop onshore and offshore fuel deposits. These activities include increased efforts by the United States to locate and recover oil and gas within unconventional deposits, such as those in the Bakken, Eagle Ford, and Marcellus Formations, using advanced drilling technologies.

Domestic barite production was about 670,000 metric tons ( $t$ ) in 2012, equivalent to about 20 percent of the domestic drilling industry's barite demand. Mine production for the United States in 2012 was about one-third of what was produced in 1980 (fig. 1). In 2012, barite imported from China was approximately 2.2 million $t$ and comprised about 77 percent of total barite imports (fig. 2) and about 70 percent of the barite used in domestic drilling. Barite from India (14 percent), Morocco (6 percent) and Mexico (2 percent) comprised the bulk of the remaining total import balance (fig. 2); drilling applications consumed nearly all barite imported from these three countries.

\section{Drilling for Oil and Gas: The Primary Use for Barite}

Oil and gas service companies, such as Baker Hughes Inc., Halliburton Co., Newpark Resources, Inc., and Schlumberger Ltd., are the leading producers and importers of barite in the United States, which makes the oil and gas drilling industry, by far, the greatest end-user of barite (Miller, 2012; 2014a). In 2012, the onshore and offshore oil and gas service industries in the United States were expected to exceed 336 million feet of combined drill-hole length (Petzet, 2012). To a lesser extent, barite is used in drilling activities for the development of fluid injection, geothermal, and water wells; and for mineral exploration. Barite's most desirable characteristic is its high specific gravity, which makes it the only mineral used in substantial tonnages to increase the density of water-based drilling muds. Drillers combine ground barite with bentonite, water, and other materials to manufacture "mud" at drill sites, and pump it down the drill hole, primarily to control high formation pressures and prevent explosive releases of oil and gas from the well. Other beneficial attributes of barite mud are that (1) it is less expensive and performs better than other materials, such as celestite, witherite, and hematite; (2) it is relatively inert, insoluble, and nontoxic; (3) it is relatively soft, and does not wear down drilling equipment; and (4) it is nonmagnetic and does not interfere with instrumentation used for logging drill holes (Alphatec Holdings, undated; Arrifan, 2003; Kammerzell, 2011; Miller, 2014a).

Although barite is critical for drilling, it is a small percentage of any drilling project's total cost, which includes all stages from the initiation of a well's drilling to its completion. For this reason, little barite is recycled for re-use beyond that "cleaned" in a centrifuge or another device at a drill site. 


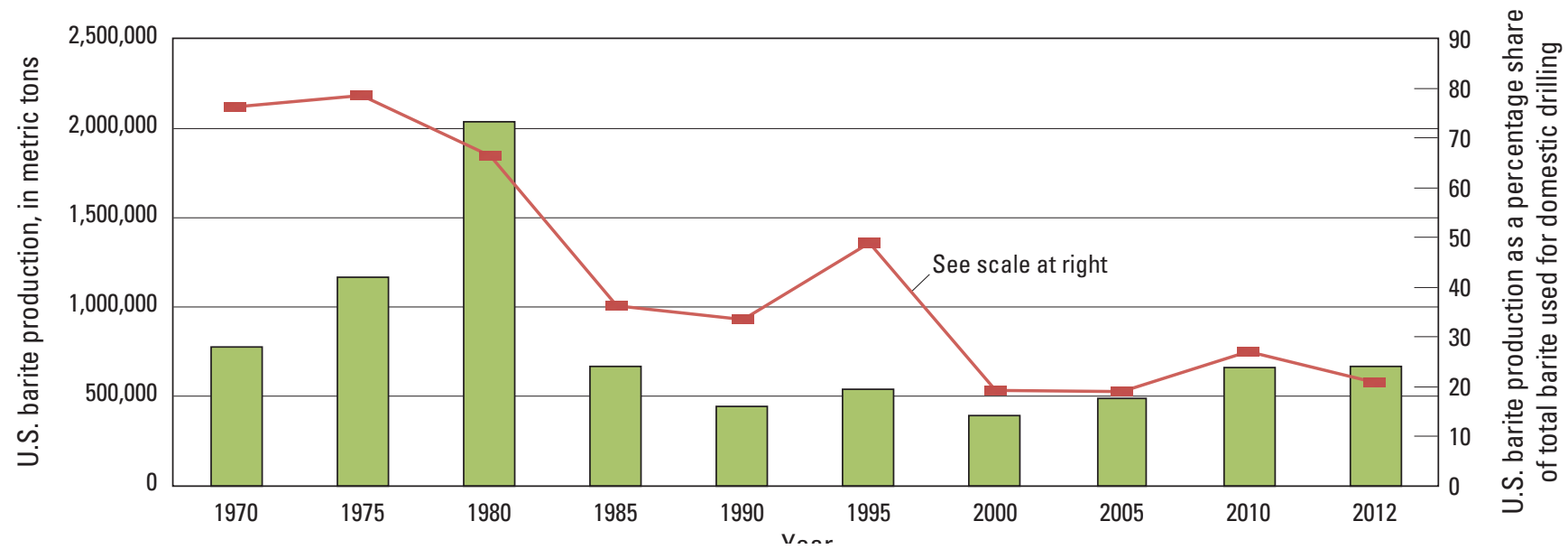

Figure 1. Comparison of domestic barite production in metric tons with its percentage share of total barite used for drilling in the United States in selected years (U.S. Bureau of Mines, 1971-1993; U.S. Geological Survey 1994-2015).

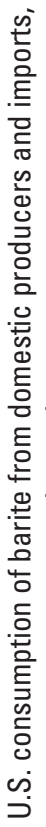
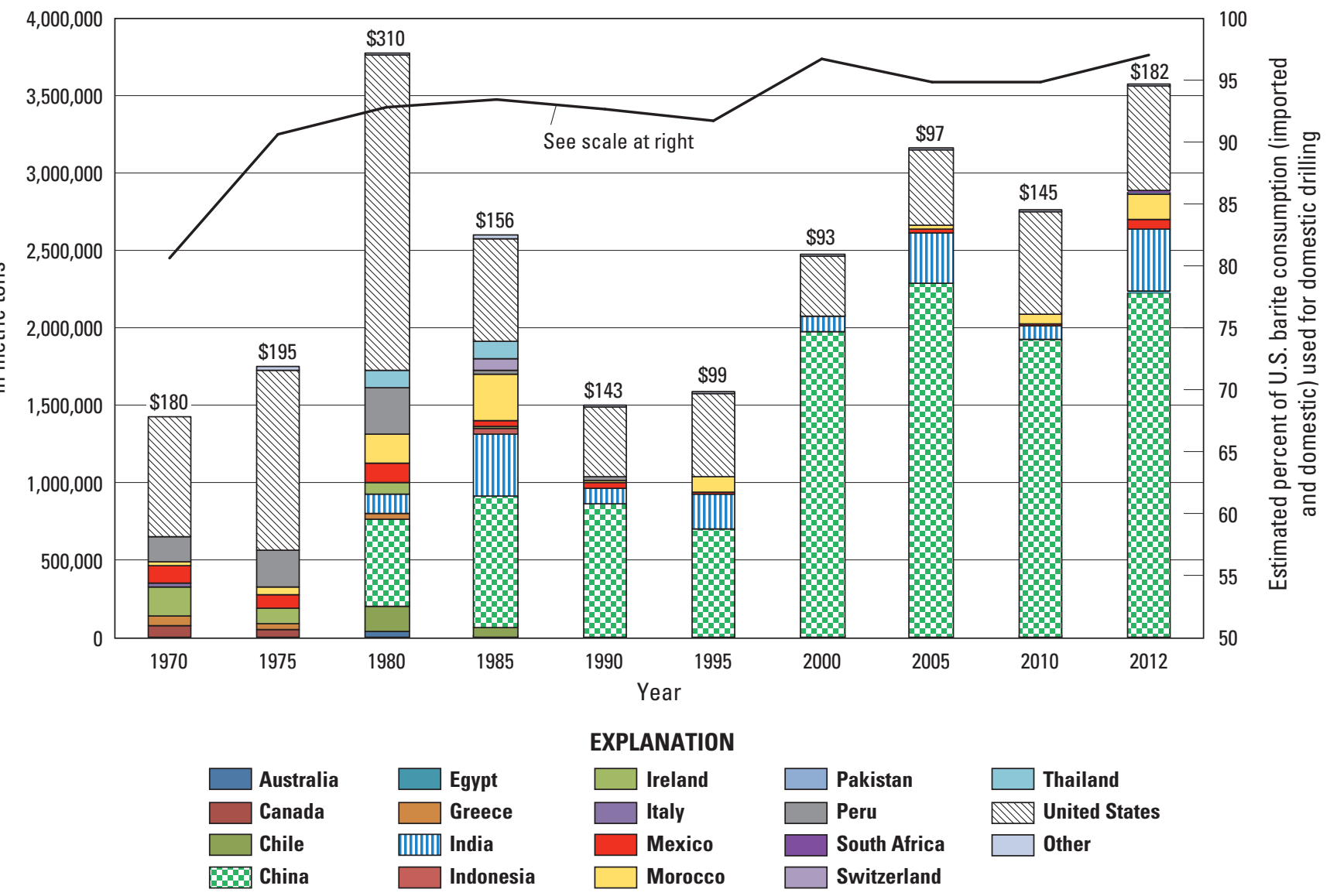

Figure 2. Metric tons of domestic and imported barite, by country, prices, and percent of U.S. barite consumption used for drilling in the United States in selected years. Prices are for drilling mud-grade crushed and ground barite per metric ton sold by processors adjusted to constant 2013 dollars using consumer price indices and rounded to the nearest dollar, as published in U.S. Geological Survey Minerals Yearbook; estimated prices may not represent the open market (Miller, 2014a; U.S. Bureau of Mines, 1971-1993; U.S. Geological Survey 1995-2014). 
However, because of increased barite prices and disposal costs, there is increased interest in the development and implementation of low-cost technologies to treat used muds that will meet specifications. Recovered muds and residues contain oil, metals, and other materials introduced during well preparation and drilling. "Used" mud, or mud no longer required or satisfactory for drilling, and residues recovered from drilling muds and cuttings, are commonly disposed of in lined pits, landfills, and placed underground by injection wells (Dual Gradient Systems LLC, 2012; New York State Water Resources Institute, 2012). The costs associated with the transport and storage of waste mud has increased, especially for offshore operations. Drill platforms are permitted to discharge drill cuttings containing barite in most coastal waters if they meet strictly enforced regulations pertaining to their composition, specifically those related to mercury and cadmium content (Bureau of Ocean Energy Management, 2014; Miller, 2014a; Veil, 1999).

The amount of barite used in a drill hole varies significantly from site to site. Factors that determine the amount of mud required include: the hole depth and diameter; the type of rock and drilling conditions, such as fractures and hole pressure; and the amount of reusable mud. A hole drilled offshore in the Gulf of Mexico to a depth of 7,500 meters (m) may use about 1,000 tof barite, roughly $40 \mathrm{t}$ per $300 \mathrm{~m}$, while onshore vertical drilling usually requires less, primarily owing to lower pressure, at roughly $11 \mathrm{t}$ per $300 \mathrm{~m}$ (Darley and Gray, 1988; Dual Gradient Systems LLC, 2012; Persistence Mining, Inc., 2013). Horizontal drilling can consume substantially less barite than vertical drilling due to lower pressures and less permeable or "tighter" oil and gas reservoir rocks (Robert S. Bailey, Supply Chain Manager, Schlumberger Ltd., oral commun., May 2, 2014; James R. Vernon, Director, Baker Hughes Inc., written commun., December 23, 2013).

In general, annual U.S. consumption of drilling muds reflects trends in drilling activity. Periods of low barite consumption and reduced drilling activity coincide with periods of low petroleum. Increased oil and gas prices, aggressive drilling programs for tapping new discoveries, and the application of new drilling and extraction technologies, such as horizontal drilling and advances in hydraulic fracturing (fracking), contribute to increased barite demand. The number of active drilling rigs and the total number of feet drilled in a certain year can correlate positively to oil and gas prices and to U.S. barite consumption (fig. 2). Price increases over the last several years reflect increased domestic and global demand, limited competition in the marketplace, and limited supply capacity.

\section{U.S. Barite Production}

Domestic mine production statistics for the years 1900 through 2012 in the U.S. indicate that the country's highest primary production of barite occurred in 1981 at 2.6 million $\mathrm{t}$ (Buckingham and others, 2014). In 1980, the second highest domestic production was achieved at just over 2 million $\mathrm{t}$ (fig. 1). The high barite consumption and record levels of domestic drilling activity resulted from the phased decontrol of domestic oil prices coupled with a nearly 100 percent increase in oil prices (Morse, 1981).

Since 1970, the United States has become increasingly dependent on foreign barite imports to satisfy the drilling industry's demand for drilling mud. In the early 1970s, domestically produced barite was an essential component for drilling mud production in the United States, meeting about 75 percent of domestic barite demand. Since 1975, the share of U.S. primary barite production used in drilling has shown a decreasing trend, and domestic production has averaged about 500,000 t per year since 1985 (fig. 1). In 2012, about $666,000 \mathrm{t}$ of barite was mined domestically, which is about 7 percent of world production and nearly 20 percent of the of the U.S. demand for barite used in drilling. Imports met the remaining 2.9 million $t$ demand (fig. 2). In 2012, nearly 97 percent ( 3.3 million $t)$ of the barite consumed in the United States was used for well drilling and accounted for about of estimated world barite consumption (Barytes Association, 2014; Miller, 2014a). Most of the nearly 150,000 $t$ of crude and ground barite exported from the United States went to western Canada. Another 107,000 t were used as extenders, fillers, or weighting agents in products such as paint, plastic, and rubber (Miller, 2014b). Approximately 80 to 85 percent of the world's consumed barite is used in drilling muds (Barytes Association, 2014; Mineral Zone, 2014). Nearly all of the barite ore produced in the United States is mined in Nevada and is ground to specifications set by the American Petroleum Institute (API), at or near the mining operations, and then transported to regional markets for use in drilling muds in California, Colorado, Montana, North Dakota, Utah, and Wyoming. Approximately 23 percent of domestic barite is exported, mostly to western Canada (Miller, 2012). Eight to ten years ago, transporting crude barite from Nevada to U.S. Gulf Coast grinding mills (which supply offshore and gulf coast drilling operations) was uneconomical, primarily due to high transportation costs and the availability of lower priced barite imports from China and other countries (Miller, 2011). Figure 2 displays the aforementioned circumstances, showing that substantial quantities of barite were imported from China in the years following 1980. With increased prices for imported barite, there has been some renewed interest in transporting domestically produced barite to major domestic markets outside of the western United States and Canada. There have already been some expansions of mining and processing operations in Nevada, where the largest domestic barite reserves and resources are located, but no major capital investments have been made to specifically increase barite shipments to the U.S. Gulf Coast (Harris, 2013; Miller, 2012). There are ongoing domestic exploration efforts to find new reserves and expand existing reserves and production at active 
operations as a result of increasing barite demand and prices (Mouat, 2014; Rasche, 2013).

Domestic inventories (stocks) of crude and ground barite are not typically large when compared with U.S. consumption, although this can change with sudden decreases in drilling activity. Substantially reduced barite exports from China could significantly decrease drilling activities and cause a major price increase; it could also lead to capital investments in exploration and production increases for barite and its substitutes, such as celestite, in the United States and other countries. Uncertainty about the duration of any interruption would hinder these efforts. Although sufficient grinding capacity exists in the United States, short-term barite supply shortages would likely occur until alternative crude barite sources could expand to meet demand, or until China renewed its exports.

\section{Barite Imports}

In 1979, China emerged as a significant barite supplier for the United States by supplying about 212,000 $t$ of barite or about 16 percent of total U.S. imports. This amount represented about 38 percent of China's estimated production (approximately 550,000 t). At that time, China generated about 7 percent of world barite production, and the United States generated about 27 percent (Morse, 1981). Barite imported to the United States from China more than doubled in 1980 to $476,000 \mathrm{t}$ and comprised about 28 percent of the total import tonnage (fig. 2). The balance of U.S. imports in 1980 was primarily met by Peru (18 percent), Morocco (11 percent), Chile ( 9 percent), India (8 percent), Mexico (7 percent), and Thailand (7 percent), as shown in figure 2 . In 2012, China, which produced an estimated 4.2 million t of barite, or 46 percent of world production, exported approximately 3.0 million $t$ of barite, of which about 2.2 million $t$ was shipped to the United States (Barytes Association, 2014; Miller, 2014a; Veil, 1999). These imports represented nearly 77 percent of total barite imports to the United States and accounted for nearly 70 percent of the 3.2 million $t$ of barite used in domestic drilling - most of the remaining barite imported to the United States originated from India (14 percent), Morocco (5 percent), and Mexico (2 percent) (figs. 1 and 2). Market shares from these countries increased significantly starting in 2011 as U.S. consumers sought to diversify their sourcing and reduce U.S. dependence on China and stabilize barite prices, which had increased substantially over the previous decade. Of the countries acting as alternative barite sources, India showed the greatest increase in barite exportation over the last few years (Miller, 2014a; Sojitz Corp., 2012). Nearly all barite imported into the United States arrives as minimally processed crude barite. Upon its arrival at U.S. seaports, crude barite is unloaded and shipped off to be ground to drilling-grade specifications. In some cases, barites of various grades and chemistries are blended to meet specifications required in drilling applications. The tariff on U.S. imports of crude barite is $\$ 1.25$ per t; no tariffs are imposed on imports of ground barite. As a result, major importers of crude barite receive foreign trade zone (FTZ) status for many of their grinding mills in the United States. An FTZ status means that the ground barite produced by these mills is reported as an import for consumption and not as crude barite received from foreign suppliers (Miller, 2014a).

\section{Domestic Barite Reserves and Resources}

Barite used in drilling muds in the United States must meet specifications defined by the American Petroleum Institute (API) (American Petroleum Institute, 2011; M-I SWACO, 2007). The primary specifications include specific gravity and composition. Barite used in drilling must have a specific gravity of 4.2 or 4.1. In the 1930s, the API set a specific gravity specification of 4.2 for barite used in drilling to ensure expected performance. In 2010, the API added an additional specification for 4.1 specific gravity barite, partially in response to dwindling domestic reserves of higher specific gravity barite (API, 2010). Barite must have a low metal content, especially in elements considered toxic. For example, barite used in drilling applications may not exceed 3 parts per million (ppm) cadmium and 1 ppm mercury (Drilling Waste Management Information System, [undated]). The acceptance of barite with a lower specific gravity was expected to result in an expansion of estimated reserves for domestic barite operations in Nevada (Newcaster, 2006). Reserve estimates are temporal, because they are affected by extraction rates, changes in barite prices, cost of delivery to the marketplace, and exploration efforts, ore quality, and other factors. One, or several factors in combination, can significantly impact reserve estimates. Foreign and domestic exploration efforts to find new reserves and expand existing reserves - as well as increased production at active operations - are ongoing in light of global and domestic increases in barite demand, rising prices, and reliance on China as the dominant supplier. In the United States, interest has renewed in exploration for reserves in Arkansas, Nevada, and Washington states by U.S. companies; new mine development and expansion at existing mines in Nevada is currently under consideration (Arkansas Geological Survey, 2014; Harris, 2013; Kent Exploration Inc., 2013; Miller, 2014a). 


\section{Summary}

The United States currently relies on foreign importation of barite to meet much of its domestic need, which has increased from about 25 percent in the 1970s to over 77 percent at present (2014). The largest, single use for barite in the United States is for use in drilling muds for the oil and gas industry, which makes the United States dependent on barite imports, mostly from China, to meet domestic requirements for drilling mud in the oil and gas industry.

U.S. reliance on imported barite has evolved as a result of low prices offered by foreign producers. Domestic barite production, which comes primarily from Nevada, is insufficient to meet national requirements. Drilling activities in the Great Plains, Western United States, and western Canada consume nearly all of Nevada's barite production. Alternative sources of barite exist, and substitutes such as celestite are available, but the international barite industry might have difficulty meeting global demand if major suppliers, specifically China, discontinued exports for an extended period of time, or if demand increased sharply.

The reliance on imported barite to supply the United States results from numerous factors, but is primarily influenced by economic conditions, which have increasingly favored imports over domestic production in recent decades. Examining the potential risk factors associated with barite supply chains - as with the foreign supply of other mineral commodities - is central to determining their future economic and strategic importance to the United States and its interest in self-sufficiency.

\section{References Cited}

Alphatec Holdings, [n.d.], Products, with a section on Barite: Alphatec Holdings Web page, accessed February 7, 2014, at http://www.alphatecinc.com/html/gallery.html.

American Petroleum Institute (API), 2010, Specification for drilling fluids materials - ANSI/API Specification 13A (18th ed.): Washington, DC, American Petroleum Institute, $109 \mathrm{p}$.

American Petroleum Institute (API), 2011, Purchasing guidelines handbook, API specification 13A, 18th edition, August 2010: API Web page, accessed June 16, 2014, at http://www.api.org/certification-programs/api-monogramprogram-and-apiqr/ /media/Files/Certification/MonogramAPIQR/program-updates/13A-18th-Edition-Purch-Guidlines-R1-2011-12-06.pdf.
Arkansas Geological Survey, 2014, Industrial mineral descriptions A-D: Arkansas Geological Survey Web page, accessed March 17, 2014, at http://www.geology.ar.gov/ minerals/ind_mineral_a_d.htm.

Arrifan, S.K., 2003, EBS 425-Mineral perindustrian: Penang, Malaysia, School of Materials and Mineral Resources Engineering, University of Science, Malaysia, 14 p., accessed February 11, 2014, at http://mineral.eng. usm.my/web\%20halaman $\% 20$ mineral/EBS\%20425\%20 -industrial $\% 20$ minerals.pdf.

Barytes Association, 2014, What is barytes?-Barytes statistics: The Barytes Association Webpage, accessed February 28, 2014, at http://www.barytes.org/statistics.html.

Buckingham, D.A., Searls, J.P., and Miller, M.M., comps., 2014, Barite statistics, in Kelly, T.D., and Matos, G.R., comps., Historical statistics for minerals and material commodities in the United States: U.S. Geological Survey Data Series 140, accessed February 6, 2014, at http://minerals. usgs.gov/minerals/pubs/historical-statistics/ds140-barit.pdf.

Bureau of Ocean Energy Management (BOEM), 2014, Questions, answers, and related resources - 5. What are drilling muds?, accessed on June 12, 2014, at http://www. boem.gov/Environmental-Stewardship/EnvironmentalAssessment/CWA/Offshore-Discharges-From-Oil-and-GasDevelopment-Operations---FAQ.aspx.

Darley, H.C.H., and Gray, G.R., 1988, Composition and properties of drilling and completion fluids (5th ed.) Houston, Tex., Gulf Publishing Company, 643 p.

Drilling Waste Management Information System, [undated], Fact sheet-Discharge to ocean: Argonne, IL, Argonne National Laboratory, accessed on December 1, 2014, at http://web.ead.anl.gov/dwm/techdesc/discharge/index.cfm.

Dual Gradient Systems LLC, 2012, DGS barite recycling plant: Dual Gradient Systems LLC Web page, 8 p., accessed February 10, 2014, at http://www.dgdrill.com/documents/ Barite\%20Recycling.pdf.

Harris, D.W., 2013, Barite mine looks to expand: Elko [Nev.] Daily Free Press, Feb. 21, 2013, accessed March 19, 2014, at http://elkodaily.com/news/local/barite-mine-looks-to-expand/ article_3d498cf0-7bd3-11e2-998c-0019bb2963f4.html.

Kammerzell, Jaime, 2011, Barite market tight as China supply decreases: Rigzone.com, Inc., 20 December, 2011, accessed February 28, 2014, at http://www.rigzone.com/news/article. asp?a_id=113495. 
Kent Exploration Inc., 2013, Kent Exploration notes substantial increase in barite prices (news release): Market Wired Web page, 27 February, 2013, accessed February 28, 2014, at http://www.marketwired.com/press-release/kent-exploration-notes-substantial-increase-in-barite-prices-tsx-venturekex-1762258.htm.

Miller, M.M., 2011, Barite [Advance Release], in Minerals yearbook volume I-Metals and minerals: U.S. Geological Survey Minerals Yearbook 2009, p. 9.1-9.8, accessed December 1, 2014, at http://minerals.usgs.gov/minerals/ pubs/commodity/barite/myb1-2009-barit.pdf.

Miller, M.M., 2012, Barite [Advance Release], in Minerals yearbook volume I-Metals and minerals: U.S. Geological Survey Minerals Yearbook 2010, p. 9.1-9.8, accessed April 1, 2014, at http://minerals.usgs.gov/minerals/pubs/ commodity/barite/myb1-2010-barit.pdf.

Miller, M.M., 2014a, Barite [Advance Release], in Minerals yearbook volume I-Metals and minerals: U.S. Geological Survey, Minerals Yearbook 2012, p. 9.1-9.11, accessed May 1, 2014, at http://minerals.usgs.gov/minerals/pubs/ commodity/barite/myb1-2012-barit.pdf.

Miller, M.M., 2014b, Barite in Mineral commodity summaries 2014: U.S. Geological Survey Mineral Commodity Summaries, p. 24-25, accessed May 1, 2014, at http://minerals.usgs.gov/minerals/pubs/commodity/ barite/mcs-2014-barit.pdf.

Minerals Zone, [n.d.], Industrial minerals-Barytes: Minerals Zone Web page, accessed February 28, 2014, at http://www.mineralszone.com/minerals/barytes.html.

M-I SWACO, 2007, M-I Wate_4.1 SG barite: Houston, Tex., M-I LLC., 3 p., accessed February 10, 2014, at http://www.slb.com/ /media/Files/miswaco/product sheets/m-i_wate_barite.ashx.

Morse, D.E., 1981, Barite in Minerals yearbook 1980, volume I-Metals and minerals: U.S. Bureau of Mines Minerals Yearbook series, p. 103-111, accessed May 1, 2014, at http://digicoll.library.wisc.edu/cgi-bin/EcoNatRes/EcoNatRes-idx? type $=$ article\&did=EcoNatRes.MinYB1980v1. DMorse\&id=EcoNatRes.MinYB1980v1\&isize=M.

Mouat, 2014, Halliburton-Dunphy, Nevada-Barite processing plant: Mouat Web page, accessed March 7, 2014, at http://www.mouat.com/mineral-processing/mineral-processing-recent-projects/halliburton-barite-grinding-plant/.
New York State Water Resources Institute, 2012, Gas wellsWaste management of cuttings, drilling fluids, hydrofrack water and produced water: New York State Water Resources Institute-Cornell University Web page, accessed May 1, 2014, at http://wri.eas.cornell.edu/gas_wells_waste.html.

Newcaster, John, 2006, Requirements for drilling grade barite, now and tomorrow-The case for adopting an alternative specification for drilling grade barite in normal applications in 18th Industrial Minerals International Congress, San Francisco, 2006, presentation, [unpaginated].

Persistence Mining, Inc., 2013, Executive summary: Persistence Mining, La Jolla, Calif., accessed February 10, 2014, at http://www.persistencemining.com/pdf/PMI\%20-\%20 Executive\%20Summary\%20Oct\%202013.pdf.

Petzet, Alan, 2012, Strong drilling year seen in 2012 in U.S., Canada: Oil \& Gas Journal, Vol. 110, issue 1a, Oil \& Gas Journal Web page accessed February 20, 2014, at http://www.ogj.com/articles/print/vol-110/issue-1a/generalinterest/sp-forecast-review/strong-drilling.html.

Rasche, John, 2013, Rossi mine plans for expansion: Elko Daily Free Press Web page, 13 June, 2013, accessed March 7, 2014, at http://elkodaily.com/mining/rossi-mineplans-for-expansion/article_c920e598-d457-11e2-89640019bb2963f4.html.

Sojitz Corp., 2012, News release-Sojitz invests in one of the world's largest barite mines in Mexico-Demand rising for use in oil and gas drilling fluid: Mexico's Secretary of Economy, Office of Mexico-Japan Economic Partnership Agreement Web page, accessed February 28, 2014, at http://www.mexicotradeandinvestment.com/pdf/2012/ julio/17/Sojitz\%20press\%20release\%20jul\%20eng.pdf.

U.S. Bureau of Mines, 1970-1993, Minerals yearbook, v. 1, 1971-1993, Bureaus of Mines mineral yearbook series, available at http://minerals.usgs.gov/minerals/pubs/ usbmmyb.html.

U.S. Geological Survey, 1995-2012, Minerals yearbookVolume I-Metals and minerals v. 1, 1995-2014, Minerals yearbook series, available at http://minerals.usgs.gov/ minerals/pubs/myb.html.

Veil, J.A., Daly, Joseph, and Johnson, Nancy, 1999, EPA speeds regs for offshore synthetic-based mud: Oil \& Gas Journal, vol. 97, issue 37, Oil \& Gas Journal Web page, accessed June 12, 2014, at http://www.ogj.com/articles/ print/volume-97/issue-37/in-this-issue/drilling/epa-speedsregs-for-offshore-synthetic-based-mud.html. 
Manuscript approved December 11, 2014

Prepared by the USGS Science Publishing Network Raleigh Publishing Service Center

Edited by Stokely J. Klasovsky

Illustrations and layout by Caryl J. Wipperfurth

For more information concerning this report, contact:

Director, National Minerals Information Center

U.S. Geological Survey

12201 Sunrise Valley Drive

988 National Center

Reston, VA 20192

Email: nmicrecordsmgt@usgs.gov

or visit our Web site at:

http://minerals.usgs.gov/minerals/ 
